\title{
PENGARUH ORGANIC SOIL TREATMENT (OST) DAN SELANG WAKTU APLIKASI LARUTAN LANDETO TERHADAP HASIL BAWANG MERAH PADA REGOSOL
}

\author{
Jeanne I. Nendissa (jeanne_frento@yahoo.com) \\ Fakultas Pertanian - UNPATTI \\ Nonce Wattimena \\ Universitas Terbuka
}

\begin{abstract}
This research was intended to determine the rate of Organic Soil Treatment (OST) and the interval of application of Landeto solution or their interaction on the growth of shallots grown in the regosol soil. This research was conducted in the green house of Departement of Soil Science, Faculty of Agriculture Gadjah Mada University. A Randomized Complete Block Design, employing a factorial treatment was chosen. The first factors was rates of OST, i.e,: 0, 3, 6, 9 and 12 ton ha ${ }^{-1}$. The second factors was interval of application of Landeto Solution, i.e, : 3, 5 and 7 days. The combination treatments were repeated 3 times. Results of the research showed that; 1) Intermedien between rates of OST at 6 ton ha- ${ }^{-1}$ and interval of application of Landeto solution ot 5 days, was found in bulb number per hills ( 29.87, cm2) respectively. 2) Application of OST, at 6 ton ha-1 had a significant effect on the plant fresh weight and the fresh bulb weigth, 3) Application of Landeto solution at different intervals had no significant effect on all components and crop yield.
\end{abstract}

Keywords : landeto solution, organic soil treatment, regosol

Bawang merah (Allium ascalonicum L.) merupakan salah satu komoditas sayuran yang mempunyai arti penting bagi masyarakat, baik dilihat dari nilai ekonomi maupun kandungan gizinya. Meskipun disadari bahwa bawang merah bukan merupakan kebutuhan pokok, akan tetapi kebutuhannya hampir tidak dapat dihindari oleh konsumen rumah tangga sebagai pelengkap bumbu masak sehari-hari. Bawang merah selain digunakan sebagai rempah juga dimanfaatkan sebagai obat tradisional untuk penyakit tertentu karena mengandung asam amino aliin yang berfungsi sebagai antibiotika (Keeler \& Tu, 1983; Maryati \& Wiryatmi, 1996).

Dalam rangka meningkatkan kuantitas dan kualitas hasil tanaman bawang merah, penanaman bawang merah secara komersial yang berorientasi pasar dan pengembangan bidang agronomi pertanaman bawang merah harus digalakkan, terutama teknik bercocok tanamnya, agar kebutuhan akan bawang merah dalam negeri tidak tergantung pada impor sehingga menghemat devisa negara.

Permasalahan yang dihadapi dalam budidaya bawang merah sekarang ini adalah: 1) penggunaan pupuk dan pestisida secara berlebihan sehingga mencemari lingkungan, 2) pengaturan drainase yang cukup sulit untuk dipenuhi dalam membudidayakan bawang merah dan 3) kondisi agroekologi yang tidak menunjang, khususnya pada lahan kritis dan lahan kering. Menurut Badan 
Pusat Statistik (2005), potensi lahan kering yang dapat dimanfaatkan seluas 20,97 juta ha. Lahan kritis dan lahan kering mengandung berbagai masalah antara lain sifat fisik, kimia dan biologinya yang kurang mendukung. Sementara itu tanaman bawang merah membutuhkan tanah yang remah dan kandungan unsur hara yang cukup tinggi, khususnya N,P dan K (Rahayu \& Nur Berlian, 1984).

Untuk meningkatkan produksi bawang merah, diperlukan ekstensifikasi maupun intensifikasi. Ekstensifikasi pada jenis tanah regosol memberikan peluang yang besar karena tanah ini memiliki konsistensi yang menguntungkan untuk pertumbuhan umbi bawang merah, namun tanah ini memiliki kekurangan sehingga diperlukan pengelolaan yang intensif melalui usaha perbaikan kesuburan tanah yaitu dengan memberikan bahan organik, karena bahan ini memperbaiki sifat fisik, kimia dan biologi tanah juga dapat menciptakan lingkungan yang sesuai dengan kehidupan mikroorganisme tanah yang menguntungkan (Larson \& Clapp, 1984; De Datta \& Hundel, 1984).

Mengingat kondisi hara makro tanah regosol sangat rendah maka penambahan pupuk anorganik sangat diperlukan. Namun demikian efisiensi pemberian pupuk anorganik sangat rendah karena rendahnya kandungan lempung maupun koloid organik pada tanah regosol. Efisiensi pemupukan dapat ditingkatkan dengan pengaturan saat pemberian dan penambahan koloid organik. Di samping itu penambahan koloid organik dapat meningkatkan daya ikat air dan kemantapan agregat tanah. Di antara koloid organik yang digunakan, Organic Soil Treatment (OST) merupakan bahan yang perlu dicobakan terutama bila pemberiannya dilakukan bersama pupuk anorganik. Produk ini telah banyak digunakan untuk tanaman hortikultura dan dikenal sebagai produk akrab lingkungan.

OST bersifat $100 \%$ organik, mengandung berbagai macam mikrobia tanah (Azotobacter, Agrobacterium, Azospirillum, Aspergillus, Rhizobium, Mycorrhiza, dll), humus konsentrat, enzim, dan protein serta tepung fosil (OST Product.Inc., 1989).

Untuk menambah hara makro sekarang telah banyak digunakan berbagai macam formula larutan. Berkaitan dengan larutan hara, permasalahan yang dihadapi sekarang adalah terlalu mahalnya biaya pengadaan larutan hara sehingga diperlukan berbagai usaha untuk pengadaan larutan hara yang mudah diramu dengan harga yang relatif murah namun kualitasnya tetap terjamin agar dapat digunakan untuk menumbuhkan tanaman dengan kualitas dan kuantitas hasil yang tinggi.

Berdasarkan penelitian yang dilakukan oleh para peneliti dari Fakultas Pertanian, Universitas Pattimura Ambon diperoleh hasil bahwa formula larutan Landeto ternyata dapat digunakan sebagai formula larutan hara. Formula larutan hara dari Landeto jauh lebih murah dibandingkan dengan larutan hara yang formulanya dari ramuan berbagai garam kimia maupun pupuk daun.

Penelitian ini bertujuan untuk mengetahui dan menentukan dosis pupuk OST dan selang waktu aplikasi larutan Landeto atau interaksinya terhadap pertumbuhan bawang merah pada regosol.

Hasil penelitian ini diharapkan dapat berguna sebagai bahan informasi masyarakat tani desa maupun para pengusaha serta sebagai bahan masukan bagi penelitian lanjutan.

\section{METODOLOGI}

Penelitian dilaksanakan di rumah kaca Jurusan IImu Tanah, Fakultas Pertanian Universitas Gadjah Mada di Kuningan. Analisis sifat fisik dan kimia tanah dilakukan di Laboratorium Ilmu Tanah Fakultas Pertanian Universitas Gadjah Mada. Analisis jaringan tanaman dilakukan di Laboratorium Tanah IP2TP Yogyakarta.

Bahan yang digunakan untuk penelitian ini adalah bibit bawang merah varietas Philippina, tanah regosol yang diambil dari dari daerah utara UPN Maguwaharjo pada kedalaman 0-30 cm 
(lapisan olah) sebagai media tanam, pupuk organik OST (Organic Soil Treatment), pupuk urea dan NPK (15:15:15). Untuk mencegah hama dan penyakit di gunakan Diazinon EC-60 dan Dithane M-45.

Alat yang digunakan dalam penelitian ini adalah polybag berukuran $25 \times 35 \mathrm{~cm}$, pH meter, ayakan dengan lubang berdiameter $5 \mathrm{~mm}$, timbangan analitik, gembor, gelas ukur dengan volume $500 \mathrm{ml}$, leaf area meter, sprayer, sekop, thermometer, label, pisau, gunting, oven listrik, alat-alat laboratorium antara lain: erlenmeyer, pipet, alat penyuling, labu didih $250 \mathrm{~mL}$, flamephotometer Eppendorf yang digunakan untuk analisis media tanam dan jaringan tanaman.

Penelitian ini dilaksanakan dengan metoda percobaan pot dan menggunakan rancangan faktorial $5 \times 3$ dalam rancangan acak kelompok lengkap (RAKL), dengan mempertimbangkan kondisi lingkungan sekitar rumah kaca yang dikelilingi dengan gedung serta banyak ditumbuhi pepohonan. Dua faktor yang dicobakan yaitu:

(a) Dosis pupuk OST (0) terdiri dari 5 aras yang meliputi :

$$
\begin{aligned}
& \text { O0 }=\text { Tanpa pupuk OST }\left(0 \text { ton ha }{ }^{-1} \text { atau } 0 \mathrm{~g} \mathrm{pot}^{-1}\right) \\
& \text { O1 }=3 \text { ton ha }{ }^{-1} \text { OST }\left(6 \mathrm{~g} \mathrm{pot}^{-1}\right) \\
& \text { O2 }=6 \text { ton ha }{ }^{-1} \text { OST }\left(12 \mathrm{~g} \mathrm{pot}^{-1}\right) \\
& \text { O3 }=9 \text { ton ha }{ }^{-1} \text { OST }\left(18 \mathrm{~g} \mathrm{pot}^{-1}\right) \\
& \text { O4 }=12 \text { ton ha }^{-1} \text { OST }\left(24 \mathrm{~g} \mathrm{pot}^{-1}\right)
\end{aligned}
$$

(b) Selang waktu aplikasi larutan Landeto (L):

$$
\begin{aligned}
& \mathrm{L} 1=3 \text { hari } \\
& \mathrm{L} 2=5 \text { hari } \\
& \mathrm{L} 3=7 \text { hari }
\end{aligned}
$$

Dari kedua faktor tersebut terdapat 15 kombinasi perlakuan. Masing-masing menggunakan 7 buah satuan percobaan dan diulang sebanyak 3 kali, sehingga secara keseluruhan digunakan sebanyak 315 satuan percobaan.

\section{Persiapan media tanam}

Tanah untuk media tanam diambil dari lapisan olah lahan di sebelah utara UPN Maguwoharjo pada kedalaman 0-20 cm. Tanah yang diambil kemudian dianginkan dan diayak dengan pengayak berdiameter lubang ayakan $5 \mathrm{~mm}$. Tanah hasil ayakan kemudian dimasukkan ke dalam polybag berisi $4 \mathrm{~kg}$ tanah. Selanjutnya OST ditaburkan secara merata pada media tanam sesuai dosis yang telah direncanakan. Media tanam ini selanjutnya dibiarkan selama satu minggu dan dikontrol pH-nya dengan $\mathrm{pH}$ meter yaitu dengan cara tanah di basahi kemudian bagian ujung $\mathrm{pH}$ meter diletakkan di atas permukaan tanah sampai pH meter menunjukkan angka yang berkisar antara 6-7 sebagai syarat tumbuh paling baik untuk tanaman bawang merah. Pada keadaan tersebut umbi bawang merah siap ditanam. Polybag yang telah berisikan media tanam diatur sesuai dengan tata letak yang telah direncanakan dengan jarak antar polybag dalam ulangan (blok) perlakuan $5 \times 10 \mathrm{~cm}$ dan antar ulangan $30 \mathrm{~cm}$.

\section{Mempersiapkan Benih dan Penanaman}

Umbi bawang merah varietas "Philippina" dengan bentuk dan ukuran yang seragam dicuci dengan air mengalir kemudian disterilkan dalam clorox (bayclin) 5\% selama 3 menit kemudian dicuci 
dengan aquadest. Benih bawang merah steril ditanam dalam polibag yang telah disiram dengan air sampai kapasitas lapangan, masing-masing satu siung.

\section{Pemupukan}

Sebagai perlakuan, OST diberikan seminggu sebelum penanaman seperti yang telah diuraikan pada butir 1. Pemupukan lanjutan menggunakan larutan Landeto yaitu larutan larutan yang mengandung urea $(46 \% \mathrm{~N})$ dan nitrophoska (15:15:15). Larutan Landeto disiapkan dengan cara melarutkan $50 \mathrm{~g}$ urea dan $70 \mathrm{~g}$ nitrophoska dalam liter air larutan stock. Dari larutan stok diambil 5 $\mathrm{mL}$ dicampur dengan 1 Liter air. Formula dari larutan stock ini dibuat dua minggu sekali sesuai kebutuhan dari volume penyiraman. Pemberian larutan landeto pada media tanam dilakukan sesuai dengan perlakuan yang dicobakan yaitu selang 3,5 dan 7 hari, dengan volume penyiraman sebagai berikut : 14-28 hst (100 mL), 28-35 hst (200 mL), 35-49 hst (300 mL) dan 49-56 hst (400 mL). Dengan demikian kebutuhan volume penyiraman tanaman bawang merah sebesar 2352 Liter.

\section{Pengendalian Hama dan Penyakit}

Pengendalian hama dan penyakit dilakukan setelah melihat adanya gejala serangan ulat grayak pada umur 28-49 hst dengan selang waktu 10 hari sekali dengan menggunakan Diazinon dan Dithane M-45 dengan konsentrasi 1,5 mL per Liter air.

\section{Pemanenan}

Panen bawang merah dilakukan setelah tanaman berumur 65 hari yaitu pada saat $60 \%$ tanaman menunjukan perubahan warna menjadi kuning agak rebah. Pada waktu tersebut umbinya sudah nampak dipermukaan. Setelah panen, umbi dijemur selama 3 hari secara merata.

\section{Pengumpulan Data}

Pengamatan komponen hasil tanaman dilakukan terhadap dua sampel meliputi:

a. Berat segar tanaman per rumpun $(\mathrm{g})$

Pengukuran berat segar tanaman per rumpun dilakukan terhadap tanaman sampel pada saat panen dengan cara menimbang tanaman yang telah dicabut dan dibersihkan.

b. Jumlah umbi per rumpun jumlah umbi per rumpun, dilakukan dengan menghitung semua umbi pada saat panen akhir.

c. Berat segar umbi per rumpun (g) tanaman sampel yang telah ditimbang berat segarnya dipisahkan dari daun dan akar kemudian ditimbang umbinya.

Untuk mengetahui perbedaan dari masing-masing perlakuan terhadap variabel yang diamati dilakukan analisis dengan menggunakan RAKL faktorial yang dilanjutkan dengan uji $F$ dengan tingkat ketilitian 99\% dan 95\%. Apabila dari uji-F menunjukan ada beda nyata dari masing-masing perlakuan maupun interaksinya, maka analisis dilanjutkan dengan uji DMRT (Duncan Multiple Range Test) dengan tingkat ketelitian 95\%. Untuk memperoleh nilai optimum atas hasil tanaman bawang merah dilakukan analisis regresi korelasi dengan tingkat ketelitian 99\% dan 95\% (Gomez \& Gomez, 1995). 


\section{HASIL DAN PEMBAHASAN}

\section{Berat segar tanaman (g)}

Tabel 1. Pengaruh OST dan Selang Waktu Aplikasi Landeto Terhadap Rata-rata Berat Segar Tanaman $(\mathrm{g})$

\begin{tabular}{ccccccc}
\hline $\begin{array}{c}\text { Selang waktu } \\
\text { aplikasi larutan } \\
\text { Landeto (hari) }\end{array}$ & \multicolumn{5}{c}{ Dosis Pupuk OST (ton ha-1) } & \multirow{2}{*}{ Rerata } \\
\cline { 2 - 6 } & 0 & 3 & 6 & 9 & 12 & \\
\hline \hline 3 & 18,7 & 25,6 & 27,9 & 23,6 & 20,9 & $23,6 \mathrm{r}$ \\
5 & 19,1 & 26,8 & 29,5 & 24,4 & 20,4 & $24,6 \mathrm{r}$ \\
7 & 19,95 & 26,9 & 28 & 22,3 & 22,7 & $23,5 \mathrm{r}$ \\
Rerata & $19,25 \mathrm{c}$ & $26,8 \mathrm{bc}$ & $28,8 \mathrm{a}$ & $23,2 \mathrm{bc}$ & $20,2 \mathrm{c}$ & $(-)$ \\
\hline
\end{tabular}

Ket : Angka rerata yang diikuti oleh huruf yang sama menunjukkan tidak berbeda nyata pada Uji Jarak Duncan $a=5 \%$ (-) Tidak ada interaksi

Data pada Tabel 1 menunjukan adanya peningkatan berat segar tanaman dengan semakin meningkatnya pupuk OST. Berat segar tanaman tertinggi dicapai pada perlakuan 6 ton ha-1 $(28,48)$ dan berbeda nyata dengan semua perlakuan yang diberikan. Berat segar tanaman terendah diperoleh pada perlakuan tanpa OST $(19,25 \mathrm{~g})$.

Regosol yang tidak diberi bahan organik dapat memiliki kemampuan memegang air yang rendah. Akibatnya air yang dapat diserap tanaman juga lebih sedikit sehingga translokasi hara, baik dari tanah ke tanaman maupun antar sel-sel tanaman itu sendiri juga lebih rendah. Kekurangan air secara seluler akan menurunkan turbiditas sel, dan menurunkan aktivitas enzim. Enzim merupakan katalisator berbagai proses biokimia di dalam tubuh tanaman, seperti pembentukan DNA dan RNA. Terganggunya proses sintesis DNA dan RNA akan berakibat negatif terhadap pembentukan sel-sel baru sehingga berat tanaman secara keseluruhan akan berkurang. Pengurangan status air dalam tubuh tanaman yang ditunjukan dengan penurunan berat tanaman (Keersebilk, 1983).

\section{Jumlah umbi per rumpun}

Tabel 2. Pengaruh OST dan Selang Waktu Aplikasi Landeto Terhadap Rata-rata Jumlah Umbi

\begin{tabular}{ccccccc}
\hline $\begin{array}{c}\text { Selang waktu } \\
\text { aplikasi larutan } \\
\text { Landeto (hari) }\end{array}$ & \multicolumn{5}{c}{ Dosis Pupuk OST (ton ha-1) } & \multirow{2}{*}{ Rerata } \\
\cline { 2 - 6 } & 0 & 3 & 6 & 9 & 12 & \\
\hline \hline 3 & $8,7 \mathrm{~b}$ & $8,9 \mathrm{~b}$ & $9,3 \mathrm{~b}$ & $9,6 \mathrm{ab}$ & $10,00 \mathrm{ab}$ & 9,35 \\
5 & $9,1 \mathrm{~b}$ & $11,1 \mathrm{ab}$ & $12,9 \mathrm{a}$ & $12,9 \mathrm{a}$ & $8,22 \mathrm{~b}$ & 10,75 \\
7 & $10,4 \mathrm{ab}$ & $10,8 \mathrm{ab}$ & $10,2 \mathrm{ab}$ & $8,5 \mathrm{~b}$ & $7,78 \mathrm{~b}$ & 9,56 \\
Rerata & 9,1 & 10,5 & 10,1 & 10,4 & 8,67 & $(-)$ \\
\hline
\end{tabular}

Ket : Angka rerata yang diikuti oleh huruf yang sama menunjukkan tidak berbeda nyata pada Uji Jarak Duncan $a=5 \%$ (-) Tidak ada interaksi 
Pada Tabel 2 dapat ditunjukkan bahwa kombinasi perlakuan 6 ton ha-1 OST dengan selang waktu 5 hari aplikasi larutan landeto menghasilkan jumlah umbi $(12,89)$ yang tidak berbeda nyata dengan perlakuan 9 ton ha-1 $(12,89)$. Namun demikian hasil uji regresi yang menggambarkan hubungan antara dosis pupuk OST dengan selang waktu aplikasi larutan Landeto menunjukkan kecenderungan kuadratik. Jumlah umbi tertinggi adalah 12,87 diperoleh pada dosis pupuk OST 5,73 ton ha ${ }^{-1}$ dan pemberian larutan landeto 5 hari sekali. Menurut Agustina (1988), hasil tanaman tergantung pada semua proses pertumbuhan yang berlangsung sebelumnya. Dengan demikian hasil ekonomis tidak saja ditentukan oleh besarnya fotosintat total yang dihasilkan, tetapi juga oleh besarnya fotosintat yang diterima organ yang benilai ekonomis.

Pemberian pupuk Organic Soil Treatment dan larutan Landeto selain menambah unsur hara tanah juga meningkatkan pemanfaatan pupuk N, P dan K dari larutan Landeto oleh tanaman dan berpengaruh positif terhadap lingkungan tanah. Formulasi OST yang mengandung berbagai macam mikrobia tanah seperti Azotobacter, Mycorrhiza, humus konsentrat, enzym, dan protein serta tepung fosil beserta kemampuannya mengaktifkan kegiatan mikrobiologi dalam tanah akan memberikan pengaruh yang cukup berarti pada perbaikan kondisi hara dalam tanah.

Menurut Soepardi (1982), bakteri tanah berperan aktif dalam semua perubahan bahan organik dan dalam reaksi enzimatik seperti nitrifikasi, fiksasi nitrogen, dan oksidasi bakteri. Hasil penelitian Goenadi, Widiastuti, Erwiyono, \& Away, (1993) menunjukkan bahwa OST mengandung bakteri Azotobacter yaitu bakteri pemfiksasi $\mathrm{N}$ atmosfer yang tidak bersimbiosis, di samping itu bakteri tersebut mampu menghasilkan auksin, vitamin, dan substansi pertumbuhan. Bakteri Azotobacter merupakan bakteri heterotropik yaitu bakteri yang memerlukan bahan organik sebagai sumber energi. OST memiliki kandungan bahan organik yang cukup tinggi sehingga dapat menjamin aktivitas dari bakteri Azotobacter.

\section{Berat segar umbi per rumpun $(g)$}

Berat segar umbi per rumpun yang dikaji dalam penelitian ini adalah berat umbi segar pada saat tanaman di panen atau tanaman telah berumur $65 \mathrm{hst}$.

Tabel 3. Pengaruh OST dan Selang Waktu Aplikasi Landeto Terhadap Rata-rata Berat Segar Umbi (g)

\begin{tabular}{ccccccc}
\hline $\begin{array}{c}\text { Selang waktu } \\
\text { aplikasi larutan }\end{array}$ & \multicolumn{5}{c}{ Dosis Pupuk OST (ton ha-1) } & \multirow{2}{*}{ Rerata } \\
\cline { 2 - 6 } Landeto (hari) & 0 & 3 & 6 & 9 & 12 & \\
\hline \hline 3 & 13,83 & 16,11 & 18,24 & 15,46 & 14,32 & $15,59 \mathrm{r}$ \\
5 & 13,2 & 16,23 & 18,62 & 15,89 & 14,35 & $15,66 \mathrm{r}$ \\
7 & 13,52 & 16,33 & 18,53 & 15,08 & 14,66 & $15,62 \mathrm{r}$ \\
Rerata & $13,51 \mathrm{c}$ & $16,22 \mathrm{ab}$ & $18,47 \mathrm{a}$ & $15,48 \mathrm{bc}$ & $14,44 \mathrm{bc}$ & $(-)$ \\
\hline
\end{tabular}

Ket : Angka rerata yang diikuti oleh huruf yang sama menunjukkan tidak berbeda nyata pada Uji Jarak Duncan $a=5 \%$ (-) Tidak ada interaksi

Pada Tabel 3 terlihat bahwa pada perlakuan 6 ton ha-1 dosis OST diperoleh berat segar umbi tertinggi $(18,47 \mathrm{~g})$ bila dibandingkan dengan perlakuan 9 ton ha-1 $(15,48 \mathrm{~g}), 12$ ton ha-1 $(14,44$ $\mathrm{g})$, tanpa OST(13,51 g) namun tidak berbeda nyata dengan perlakuan 3 ton ha-1 $(16,22 \mathrm{~g})$. Hal ini 
menunjukkan bahwa serapan $\mathrm{N}$ yang tinggi pada tanaman yang diberi pupuk OST (6 ton ha-1) menyebabkan meningkatnya laju asimilasi bersih.

Hal ini dibuktikan dengan uji korelasi antar parameter pengamatan, dimana berat segar umbi berhubungan positif dengan tinggi tanaman $\left(0,33^{*}\right)$, jumlah daun $\left(0,40^{* *}\right)$, nisbah tajuk akar $\left(0,43^{* *}\right)$, dan laju asimilasi bersih $\left(0,44^{* *}\right)$. Memasuki fase pertumbuhan generatif, produksi bahan kering yang tinggi dialokasikan untuk pengisian dan pembentukan umbi.

\section{KESIMPULAN}

Berdasarkan hasil penelitian yang diperoleh, dapat ditarik kesimpulan sebagai berikut :

1. Penggunaan OST pada dosis 6 ton ha-1 menghasilkan pertumbuhan dan hasil bawang merah terbaik yang dinyatakan pada berat segar tanaman (g), jumlah umbi per rumpun, berar segar umbi per rumpun $(\mathrm{g})$

2. Pemberian larutan Landeto dengan selang waktu 3, 5 dan 7 hari tidak berpengaruh nyata terhadap hasil bawang merah.

3. Pada umur $49 \mathrm{hst}$, terjadi interaksi antara perlakuan dosis pupuk OST dengan selang waktu aplikasi larutan Landeto pada jumlah umbi bawang merah dengan kombinasi perlakuan OST 6 ton ha-1 dan pemberian larutan Landeto 5 hari sekali.

Larutan stock formula Landeto yang sudah disimpan terlalu lama sebaiknya jangan digunakan, karena akan mengakibatkan kegagalan bagi tanaman yang dibudidayakan. Hal ini disebabkan larutan tersebut telah mengalami perubahan-perubahan dalam sifat fisik maupun susunan kimianya, yang mengarah pada terjadinya pembentukan senyawa lain yang bersifat racun bagi tanaman.

\section{REFERENSI}

Agustina, R. (1988). Pengaruh pemberian IAA dan ketersediaan unsur hara S terhadap kecepatan pertumbuhan, kandungan $S$ dan protein pada Allium cepa Var. Ascalonicum (L). Bark (Bawang Mearh). Program Pasca Sarjana. Yogyakarta: Univeresitas Gadjah Mada.

Badan Pusat Statistik. (2005). Statistika Indonesia. Jakarta: Badan Pusat Statistik.

De Datta, S.K., \& Hundel, S.S. (1984). Effect of organic matter management on land preparation and structural cropping system. IRRI. Los Banos: In: Organic Matter and Rice.

Goenadi, D.H., Widiastuti, H., Erwiyono, R., \& Away, V. (1993). Pemanfaatan organic soil treatmeant (OST) sebagai sumber bahan organik dan aktifaktor kompos. Bogor: PT Radjawali Pharma Jaya, \& Pusat Penelitian Bioteknologi Bogor.

Gomez, K.A., \& Gomez, A.A. (1995). Prosedur statistik untuk penelitian pertanian. Penerjemah Endang Sjamsuddin, Justica S. Baharsjah. Jakarta: Penerbit Universitas Indonesia.

Keeler, R.F., \& Tu, A.T. (1983). Handbook of natural toxins. New York: Marcel Dekker, Inc. Keersebilk, (1983). Soil plant water relationship. Yogyakarta: Dept. of Soil Science Fac. of Agricultural. Univ. of Gadjahmada.

Larson, W.E., \& Clapp, C.E. (1984). Effect of organic matter on soil physical properties in organic matter and rice. Philippines: IRRI. 
Maryati \& Wiryatmi. (1996). Budidaya bawang merah di Yogyakarta. Jakarta: Deptan.

OST Product Inc. (1989). A soil regenerator, OST. Brosur. OST Produst, Lbc, Ltd.

Rahayu, E., \& Nur Berlian, V.A. (1984). Bawang merah. Jakarta: Penebar Swadaya.

Soepardi, G. (1982). Pengembangan lahan pertanian di lahan kering dan upaya peningkatan produktivitas lahan. Bogor: Institut Pertanian Bogor. 